\title{
MODEL KONSEPTUAL PENINGKATAN KUALITAS LAYANAN INDUSTRI PARIWISATA DI JAWA TENGAH MENGGUNAKAN TOURSERVQUAL
}

\author{
Novi Marlyana dan Nuzulia Khoiriyah \\ Jurusan Teknik Industri Fakultas Teknologi Industri \\ Universitas Islam Sultan Agung \\ Email:novi@unissula.ac.id
}

\begin{abstract}
Several previous studies have found factors or dimensions that affect the quality services of tourism and measures the perceived level of tourists as consumers. However, these studies have not been able to develop a practical model of a system as a simple overview of the tourism industry by involving various factors / dimensions that influence. This research will make a conseptual model of the service quality improvement of the tourism industry in the province of Central Java. The method used in this paper is Tourservqual, which is the Service Quality methods applied in the field of tourism. The resulting conceptual model consists of sixteen (16) dimension of the quality of tourism services that will affect or have a positive relationship with customer satisfaction (tourists). Customer satisfaction has a positive influence on destination competitiveness. Destination competitiveness measured in 36 indicators. This conceptual model expected to measure tourist satisfaction who becomes the object of the tourist areas, also measure the level of competitiveness of each of these objects, as well as knowing what factors most affect the competitiveness of tourist destinations.
\end{abstract}

Keywords: Service quality, Tourism, Model, Tourservqual

\begin{abstract}
ABSTRAK
Beberapa penelitian terdahulu telah menemukanfaktor atau dimensi yang berpengaruh terhadap kualitas layanan pariwisata dan mengukur tingkat persepsi wisatawan sebagai konsumen. Namun penelitianpenelitian tersebut belum mampu menyusun suatu model praktis sebagai gambaran sederhana suatu sistem industri pariwisata dengan melibatkan berbagai faktor/dimensi yang mempengaruhi. Pada penelitian ini akan membuat suatu model konseptual peningkatan kualitas layanan industri pariwisata di Provinsi Jawa Tengah. Metode yang digunakan dalam tulisan ini adalah Tourservqual, yaitu metode Service Quality yang diterapkan pada bidang tourism. Model konseptual yang dihasilkan terdiri dari enam belas (16) dimensi kualitas layanan pariwisata yang akan mempengaruhi atau memiliki hubungan yang positif dengan kepuasan pelanggan (wisatawan atau turis). Kepuasan pelanggan memiliki pengaruh yang positif terhadap keunggulan daerah wisata (destination competitiveness). Untuk mengukur daya saing (keunggulan) daerah wisata menggunakan 36 indikator. Model konseptual ini nantinya diharapkan dapat mengukur kepuasan wisatawan diantara daerah wisata yang menjadi objek, juga mengukur tingkat daya saing masing-masing objek tersebut, sekaligus mengetahui faktor apa yang paling berpengaruh terhadap daya saing tujuan wisata.
\end{abstract}

Kata kunci: Kualitas layanan, Pariwisata, Model, Tourservqual 


\section{PENGANTAR}

Dalam rangka Visit Jawa Tengah 2013, Dinas Kebudayaan dan Pariwisata Provinsi Jawa Tengah terus melakukan upaya secara simultan agar Provinsi Jawa Tengah benar-benar siap untuk menyambut tahun kunjungan wisata tersebut. Beberapa hal yang disiapkan antara lain dengan pembenahan berbagai sarana dan penyiapan masyarakat dalam menyongsong tahun tersebut. Tahun kunjungan wisata 2013 merupakan sebuah gerakan untuk meningkatkan kepedulian semua pihak untuk menyadari bahwa Jawa Tengah memiliki potensi luar biasa, tetapi belum dimanfaatkan untuk menghasilkan pendapatan bagi warga masyarakat secara luas.

Menurut data dari Badan Pusat Statistik Jawa Tengah, jumlah wisatawan mancanegara yang berkunjung ke provinsi Jawa Tengah melalui pintu masuk Bandara Adi Sumarmo selama 2012 menurun 9,31 persen dibanding 2011. Jumlah wisatawan mancanegara (wisman) yang berkunjung ke Jateng secara kumulatif (Januari-Desember) selama tahun 2011 sebanyak 23.830 orang dan turun menjadi 21.612 orang pada tahun 2012 (www.antarajateng.com). Target subjek wisatawan juga mencakup bagi wisatawan nusantara (wisnus). Kenali Negerimu, Cintai Negerimu menjadi slogan bagi pengembangan pariwisata Indonesia khususnya bagi wisnus.

Jika melihat pada bentuk proses maupun produk yang dihasilkan, industri pariwisata tergolong dalam industri jasa. Purwanto (2004) dalam Liangi, et al (2010) menyatakan bahwa pariwisata seperti layaknya suatu industri yang menghasilkan produk, produk wisata berbentuk jasa, dimana pariwisata merupakan sekumpulan atribut yang mencakup atraksi, paket, harga, prestige serta pelayanan yang mungkin diterima pengunjung sebagai sesuatu yang dapat memuaskan kebutuhan dan keinginan dalam memperoleh pengalaman.Sebagai salah satu sektor penunjang ekonomi masyarakat dan juga penyumbang devisa negara, maka peningkatan layanan kualitas di bidang pariwisata mutlak harus dilakukan. Intensitas kedatangan para wisatawan dipengaruhi oleh kepuasan konsumen akan kualitas layanan pariwisata. Atilgan, et. al.(2003) menyatakan bahwa kualitas di bidang pariwisata merupakan faktor penting dan pada akhirnya menentukan keberhasilan usaha pariwisata. World Tourism Organization (2003) mendefinisikan kualitas layanan di bidang pariwisata adalah sebagai berikut: “...hasil dari suatu proses yang menyiratkan kepuasan dari semua produk yang sah dan kebutuhan akan pelayanan, persyaratan dan harapan pelanggan, dengan harga yang dapat diterima, sesuai dengan penentu kualitas yang mendasari seperti keselamatan dan keamanan, kebersihan, aksesibilitas, transparansi, keaslian, dan harmonisasi dari kegiatan pariwisata yang peduli dengan lingkungan manusia dan alam".

Terdapat beberapa penelitian terdahulu yang membahas tentang kualitas layanan di bidang pariwisata atau yang dikenal dengan istilah asingnya adalah tourism service quality (tourseroqual). Para penulis tersebut antara lain: Atilgan, et.al. (2003), Martin-Cejas (2006), Eraqi (2006), Prabaharan, et. al. (2008), Sulistiyani (2010), dan Haghkhah et. al. (2011). Tourism service quality (tourservqual) merupakan metode yang digunakan untuk mengukur kualitas layanan (jasa) yang terdapat pada industri pariwisata. Kualitas layanan bersifat abstrak (Haghkhah et al., 2011). Dalam Prabaharan et al. (2008) juga disebutkan bahwa sebagai sebuah metode, ServQual, telah ditawarkan sebagai sebuah model guna mengukur kualitas jasa selama lebih dari 10 tahun dan model ini dapat diterapkan pada beragam konteks layanan. Telah banyak peneliti dalam bidang pariwisata yang menggunakan model ini untuk mengevaluasi kualitas layanan yang diberikan dalam bidang pariwisata dan industri-industri terkait. Metode ServQual diperkenalkan oleh Parasuraman (Atilgan et al, 2003, Hung-Chih Yu, 2005, Eraqi, 2006, Prabaharan et al., 2008, Jin Zhang, 2009) yang mendefinisikan konsep kualitas layanan ke dalam 5 (lima) dimensi utama, yaitu: kehandalan (reliability), daya 
tanggap (responsiveness), jaminan (assurance), bukti fisik (tangibles), dan empati (emphaty). "Reliability" secara umum didefinisikan sebagai kemampuan untuk memberikan layanan yang dijanjikan secara tepat dan dapat dipercaya. "Responsiveness" merupakan kesediaan untuk membantu konsumen dan memberikan layanan dengan cepat. "Assurance" meliputi pengetahuan dan kesopanan karyawan serta kemampuannya untuk menyampaikan kepercayaan. "Emphaty" didefinisikan sebagai kesediaan untuk memberikan perhatian secara individu kepada pelanggan (Atilgan et al., 2003).

Menurut Eraqi (2006), pariwisata merupakan industri yang sangat kompetitif, dan sektor usaha pariwisata tidak dapat hanya bersaing dengan hanya berdasarkan pada biaya saja. Kualitas merupakan sebuah elemen kunci bagi persaingan dalam industri pariwisata. Kualitas juga penting bagi industri pengembangan pariwisata yang berkelanjutan. Atilgan et al (2003) juga menegaskan bahwa kualitas dalam bidang pariwisata merupakan sebuahfaktor penting dan akhirnya menentukan kesuksesan dalam bisnis pariwisata. Prabaharan et al. (2008) dalam penelitiannya menggunakan metode Service Quality (ServQual) dalam mengukur kualitas layanan pariwisata, khususnya persepsi kualitas layanan dari turis domestik dan turis asing. Haghkhah (2008) melakukan penelitian terkait pengaruh dari tiap dimensi kualitas layanan (service quality) terhadap pariwisata.

Merujuk pada penelitian-penelitian tersebut maka banyak faktor yang berpengaruh terhadap kualitas layanan suatu industri/ usaha pariwisata. Akan tetapi, faktorfaktor tersebut hanya sebatas digunakan dalam mengukur tingkat kualitas layanan dan belum mampu membuat suatu model kualitas layanan ideal yang dibutuhkan dari suatu industri pariwisata. Mempelajari sistem, termasuk sistem industri pariwisata, akan lebih mudah bila kita membangun model dari sistem tersebut. Sedangkan pengertian model adalah gambaran atau proyeksi dari suatu obyek atas sistem yang sebenarnya.
Kajian ini akan disusun suatu model konseptual kualitas layanan industri pariwisata di Propinsi Jawa Tengah. Diharapkan dengan adanya penelitian ini dapat diketahui model yang tepat bagi kualitas layanan dari industri pariwisata di Propinsi Jawa Tengah sehingga dapat menghasilkan peningkatan kualitas layanan tersebut. Tujuan akhirnya adalah dapat meningkatkan jumlah wisatawan yang berkunjung dan meningkatkan pertumbuhan ekonomi daerah yang akan pula meningkatkan ekonomi nasional. Kajian ini dilakukan berdasarkan studi literatur dari berbagai literatur yang membahas tentang kualitas layanan di bidang pariwisata, dimensi-dimensi yang mempengaruhi kualitas layanan, hingga faktor-faktor guna mengukur daya saing wisata guna mencapai kepuasan wisatawan. Berikut adalah alur metode penelitian yang dilakukan dalam penelitian ini:

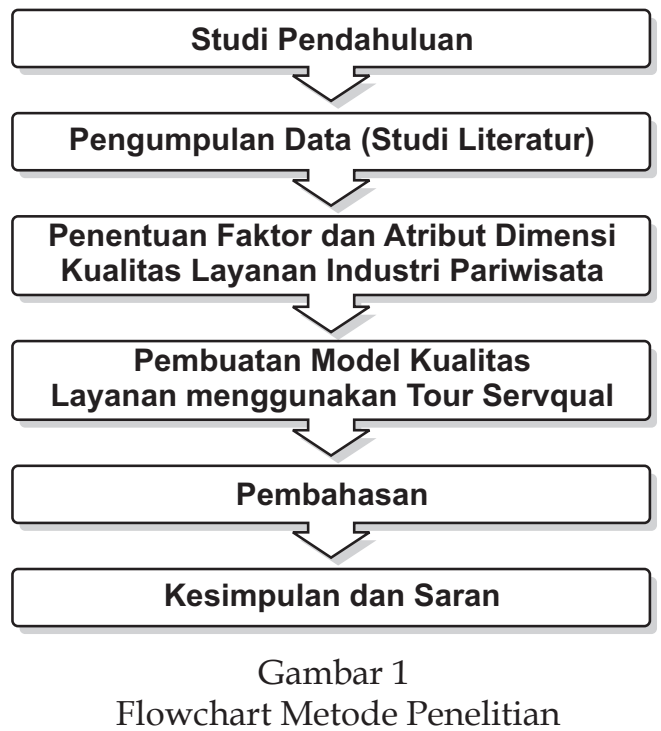

Dasar pengukuran kualitas layanan pariwisata awalnya masih mengacu pada dimensi kualitas layanan Service Quality (ServQual) milik Parasuraman. Faktor dan atribut yang digunakan dalam model merupakan alat ukur dalam menilai kepuasan wisatawan berdasarkan konsep utama dari ServQual tersebut. Tour Servqual juga disusun berdasarkan lima dimensi jasa seperti pada ServQual, yaitu :Reliability, Assurance, Tangible, Emphaty, dan Responsiveness. 
Terdapat beberapa dimensi dari hasil penelitian terkait service quality in tourism yang digunakan untuk membangun model konseptual ini, yaitu penelitian: Zhang (2004), Tsaur et al. (2004), Hung-Chih Yu (2005), Eraqi (2006), Ho (2007), Caro (2008), Prabaharan et al. (2008), Narayan et al. (2008), Sulistiyani (2010), Moon (2011), dan Haghkhah et al. (2011). Kemudian tiap dimensi tersebut diperbandingkan, dianalisa dan menghasilkan 6 penelitian utama yang memberikan 16 dimensi yang digunakan secara bersama pada penelitian-penelitian tersebut.

Penjelasan dari enam penelitian utama tersebut adalah sebagai berikut:

Hung-Chih Yu (2005) yang mengadopsi empat dimensi kualitas layanan (responsiveness, reliability, assurance dan tangible) milik Parasuraman dalam penelitiannya. Namun untuk melengkapi penelitiannya, Yu menambahkan satu dimensi lain di luar ServQual yaitu participant dalam penelitiannya yang berjudul "Service Quality : A Case Study of the 2011 Study Tour of Taiwan". Terdapat penelitian lainnya yang juga menggunakan dasar dimensi kualitas ServQual sebagai referensi, yaitu Zhang (2009). Penelitian Zhang, yaitu : "An Investigation Into the Guests' Perceived Service Quality of the Bed-And-Breakfast and Guest House Market Industry in the Nelson Mandela Bay Area". Zhang menggunakan 4 dimensi kualitas layanan dalam penelitiannya. Keempat dimensi tersebut antara lain :responsiveness, reliability, assurance, tangible. Berbeda dengan Hung-Chih Yu (2005)dan Zhang (2009) yang masih menggunakan dimensi kualitas milik Parasuraman. Eraqi (2006) membuat penelitian yang dipublikasikan di Jurnal Emerald yang berjudul“ Tourism ServiceQuality (TourServQual) in Egypt". Dalam penelitiannya tersebut Eraqi ingin melihat sudut pandang pelanggan dalam hal ini adalah para wisatawan terhadap layanan kualitas di Egypt. Eraqi menggunakan dimensi pengukuran yang dikeluarkan oleh WTO yaitu :safety and security, hygiene, accessibility, transparency, authenticity, harmony. Selain penelitian yang bertujuan untuk menguji kualitas layanan pariwisata di suatu daerah, ada penelitian lain yang mencoba untuk membuat patokan skala pengukuran ServQual (SQ) ada juga yang mencoba untuk membuat model kualitas layanan pariwisata. Narayan et. al (2008) melakukan penelitian yang berjudul "Scales to measure and benchmark service quality in tourism industry:A second-order factor approach". Tujuan dari penelitian tersebut adalah untuk mengembangkan dan memvalidasi skala untuk mengukur kualitas pelayanan dan patokan (SQ) dalam industri pariwisata. Instrumen yang digunakan oleh Narayan et al dalam penelitiannya adalah: safety and security, hospitality, hygiene, information, food. Instrumen penelitian yang digunakan berbeda dengan 5 dimensi kualitas jasa milik Parasuraman. Prabaharan (2008) dalam tulisannya yang berjudul "Service Quality on Tourism: Application of Structural Equation Modelling " menggunakan enam dimensi untuk membuat model layanan kualitas pariwisata di Kerala dari aspek sudut pandang wisatawan dalam negeri dan wisatawan mancanegara. Enam dimensi yang digunakan dalam penelitian tersebut adalah: responsiveness, reliability, assurance, tangible, service responsibility, service product. Prabaharan mencoba untuk mengembangkan model kualitas layanan milik Parasuraman dengan tidak memasukkan dimensi emphaty namun menambahkan dua dimensi baru yaitu service responsibility dan service product.Selain beberapa peneliti di atas, terdapat Moon,et. al.(2011) yang membuat penelitian berjudul: "The influence of consumer's event quality perception on destination image". Moon membuat model untuk mengukur keterkaitan antara event quality dengan destination image. Dalam penelitiannya Moon menggunakan dimensi ServQual dan beberapa dimensi tambahan lainnya. Dimensi yang digunakan antara lain: responsiveness, reliability, safety and security, communication, hospitality.

Berdasarkan beberapa referensi tersebut, maka dalam membuat model kualitas layanan pariwisata Jawa Tengah menggabungkan semua dimensi tersebut, hingga terdapat 16 dimensi yang digunakan. Proses pembentukan dimensi-dimensi tersebut dapat dijelaskan pada skema di bawah ini: 
Gambar 2

Skema Penentuan Dimensi dalam Model Konseptual

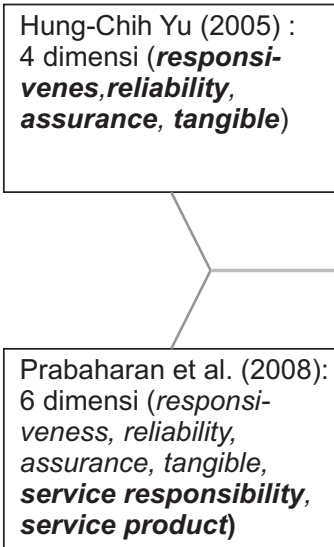

Kemudian untuk mengukur dimensi kepuasan pelanggan kami mengacu pada penelitian Kangogo (2013). Kangogo menggunakan indikator :length of stay, customer loyalty, repeat sales, referrals, handling customer complain dan guest retention sebagai indikator customer satisfaction pada model. Kepuasan wisatawan merupakan indikator yang mempengaruhi daya saing dari tujuan wisata. Selanjutnya kami menggunakan penelitian Crouch (2007) untuk mengukur destination competitiveness dari lokasi wisata. Menurut Crouch (2007), daya saing tujuan wisata dapat diukur melalui 36 faktor.

\section{PEMBAHASAN}

Hubungan yang dibangun dalam model diawali oleh keterkaitan antara kepuasan konsumen (wisatawan) yang akan mempengaruhi daya saing tujuan (destinasi) wisata.

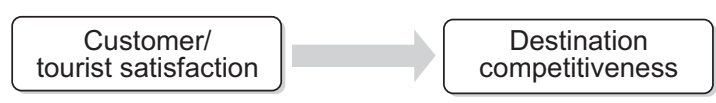

Gambar 3

Hubungan antara Kepuasan Konsumen dan Daya Saing Tujuan Wisata

\section{Dimensi dan Faktor Digunakan dalam Model}

Terdapat 16 dimensi yang akan mempengaruhi kepuasan konsumen (wisatawan). Keenam belas dimensi tersebut dirangkum berdasarkan referensi yang digali dari berbagai literatur terkait kepuasan wisatawan dalam penilaian kualitas layanan pariwisata.

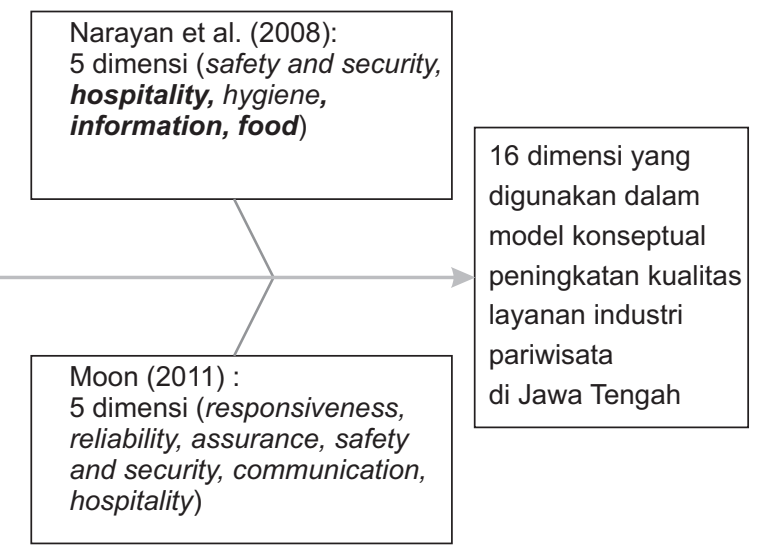

Dimensi-dimensi tersebut sebagai berikut: (1) Responsiveness (Daya Tanggap), (2) Reliability (Kehandalan), (3) Assurance (Jaminan) Assurance (Jaminan), (4) Tangible (Bukti Fisik), (5) Safety $\mathcal{E}$ Security (keselamatan dan Keamanan), (6) Communication (Komunikasi), (7) Hospitality/ Friendliness (Keramah tamahan), (8) Hygiene (Kesehatan), (9) Accessibility (kemudahan untuk diakses), (10) Transparency (Transparansi), (11) Authenticity (Keaslian), (12) Harmony (Keserasian / keselarasan), (13) Information (Informasi), (14) Service responsibility (tanggung jawab layanan), (15) Service product (produk layanan), dan (16) Food (Makanan). Kemudian menurut Crouch (2007) terdapat 36 faktor yang mempengaruhi daya saing tujuan wisata sebagai berikut:

- Sumber dan daya tarik utama

1) Acara khusus

2) Fisiografi dan iklim

3) Budaya dan sejarah

4) Ragam aktivitas

5) Hiburan

6) Superstruktur

7) Hubungan pasar

- Faktor dan Sumber Pendukung

1) Infrastruktur

2) Aksesibilitas

3) Sumber daya pendukung

4) Keramahan

5) Perusahaan/firma

5) Kebijakan politik 
- Kebijakan, perencanaan dan pengembangan destinasi
1) Definisi sistem
2) Filosofi/nilai
3) Visi
4) Posisi/merk
5) Pengembangan
5) Analisis kompetitif/kolaborasi
6) Monitoring dan evaluasi
7) Audit

- Manajemen destinasi
1) Organisasi
2) Pemasaran
3) Kualitas jasa/pengalaman
4) Informasi/penelitian
5) Pengembangan sumber daya manusia

6) Pembiayaan dan modal usaha

7) Manajemen tamu

8) Manajemen krisis

9) Pelayanan sumber daya

- Persyaratan dan penjelasan faktor penentu
1) Lokasi
2) Keselamatan/keamanan
3) Biaya/nilai
4) Ketergantungan
5) Kesadaran/gambaran
6) Kapasitas bawaan

\section{Konseptual Penelitian}

Berikut ini disusun suatu model konseptual berdasarkan uraian sebelumnya:

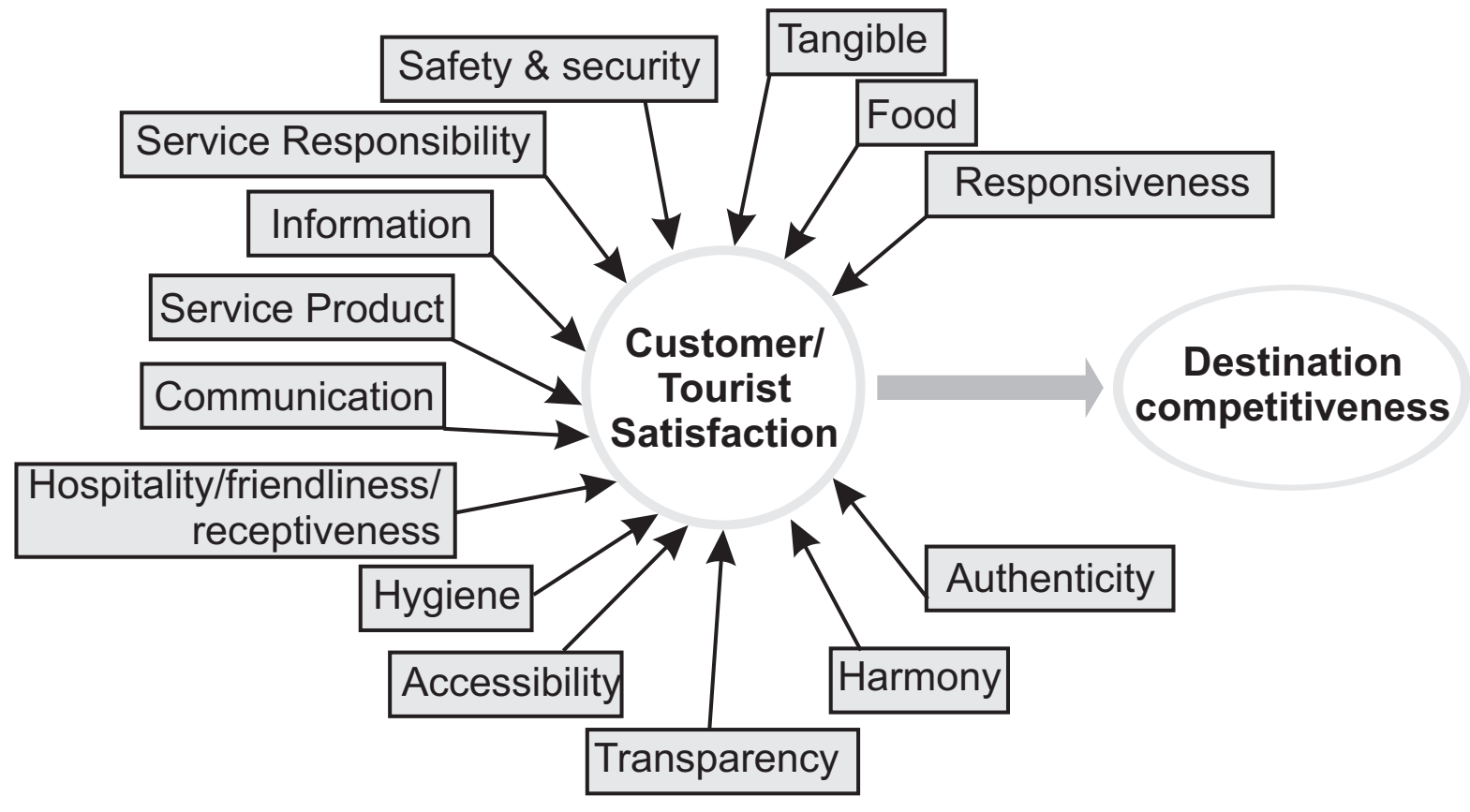

Gambar 4

Model Konseptual Peningkatan Kualitas Layanan Wisata

\section{Indikator Penelitian}

Diuraikan indikator riset yang terkait dengan 16 dimensi yang mempengaruhi kepuasan wisatawan dan 36 faktor yang digunakan dalam mengukur daya saing tujuan wisata: 
Tabel 1

Indikator Penelitian

\begin{tabular}{|c|c|c|c|}
\hline Variabel Laten & & Indikator & Sumber \\
\hline \multirow{9}{*}{$\begin{array}{l}\text { Responsiveness } \\
\text { (Daya Tanggap) }\end{array}$} & D1 & Petugas bersungguh-sungguh dalam memecahkan masalah & \multirow{9}{*}{$\begin{array}{l}\text { Prabaharan (2008), } \\
\text { Moonet al(2011), } \\
\text { Hung-Chih Yu } \\
\text { (2005), Zhang } \\
(2009)\end{array}$} \\
\hline & $\mathrm{D} 2$ & Respon yang cepat terhadap keinginan wisatawan & \\
\hline & D3 & $\begin{array}{l}\text { Kesediaan untuk membantu wisatawan, dan } \\
\text { menyarankan bagaimana menggunakan waktu luang }\end{array}$ & \\
\hline & $\mathrm{D} 4$ & Permasalahan dapat dipecahkan secepatnya & \\
\hline & D5 & Petugas merespon permintaan secepatnya. & \\
\hline & D6 & Petugas bersedia menjawab pertanyaan wisatawan. & \\
\hline & $\overline{\mathrm{D} 7}$ & $\begin{array}{l}\text { Daya tanggap petugas di tempat menginap untuk } \\
\text { menangani keluhan }\end{array}$ & \\
\hline & D8 & $\begin{array}{l}\text { Daya tanggap penduduk di luar tempat menginap untuk } \\
\text { membantu }\end{array}$ & \\
\hline & D9 & Sikap dan perilaku petugas & \\
\hline \multirow{13}{*}{$\begin{array}{l}\text { Reliability } \\
\text { (Kehandalan) }\end{array}$} & H1 & Melakukan pelayanan dengan benar sejak pertama kali & \multirow{13}{*}{$\begin{array}{l}\text { Prabaharan (2008), } \\
\text { Moon et al (2011), } \\
\text { Hung-Chih Yu } \\
\text { (2005), Zhang } \\
(2009)\end{array}$} \\
\hline & $\mathrm{H} 2$ & Tepat janji & \\
\hline & $\mathrm{H} 3$ & Memenuhi jadwal tur & \\
\hline & $\mathrm{H} 4$ & Tidak ada kenaikan biaya tur secara mendadak & \\
\hline & $\mathrm{H} 5$ & Informasi disediakan secara tepat dan akurat & \\
\hline & $\mathrm{H} 6$ & Apa yang dijanjikan itu yang diberikan & \\
\hline & H7 & Kegiatan/program dimulai tepat waktu & \\
\hline & $\mathrm{H} 8$ & $\begin{array}{l}\text { Peralatan yang disediakan bagi program tersebut harus } \\
\text { terkini (up-to-date) }\end{array}$ & \\
\hline & H9 & $\begin{array}{l}\text { Penyelenggara/pemilik harus memperhatikan } \\
\text { pengendalian kualitas }\end{array}$ & \\
\hline & $\mathrm{H} 10$ & Pemesanan tempat (reservasi) ditangani secara efisien. & \\
\hline & H11 & Ruang/kamar siap sesuai yang dijanjikan & \\
\hline & H12 & $\begin{array}{l}\text { Peralatan mekanis bekerja dengan tepat/baik } \\
\text { (seperti:TV) }\end{array}$ & \\
\hline & H13 & Saya dapatkan apa yang telah saya bayarkan & \\
\hline \multirow{12}{*}{$\begin{array}{l}\text { Assurance } \\
\text { (Jaminan) }\end{array}$} & A1 & Dilayani oleh petugas yang tepat & \multirow{12}{*}{$\begin{array}{l}\text { Prabaharan (2008), } \\
\text { Hung-Chih Yu } \\
\text { (2005), Zhang } \\
(2009)\end{array}$} \\
\hline & A2 & Penguatan kepercayaan wisatawan & \\
\hline & A3 & $\begin{array}{l}\text { Pendampingan jasa tur dan hotel yang kompeten dan } \\
\text { berpengalaman }\end{array}$ & \\
\hline & A4 & Petugas harus dapat dipercaya & \\
\hline & A5 & Petugas yang dapat dipercaya di tempat menginap & \\
\hline & A6 & $\begin{array}{l}\text { Penduduk yang dapat dipercaya diluar tempat } \\
\text { menginap }\end{array}$ & \\
\hline & A7 & Petugas harus sopan & \\
\hline & A8 & Petugas harus kompeten & \\
\hline & A9 & Petugas harus memahami kebutuhan saya & \\
\hline & A10 & $\begin{array}{l}\text { Petugas harus mengerjakan tugas mereka dengan baik } \\
\text { secara konsisten }\end{array}$ & \\
\hline & A11 & Petugas membuat kita merasa seperti ini kepunyaan kita & \\
\hline & A12 & Petugas harus bersemangat & \\
\hline Tangible (Bukti & F1 & Kendaraan yang modern dan relevan secara teknologi & \multirow{6}{*}{$\begin{array}{l}\text { Prabaharan (2008), } \\
\text { Hung-Chih Yu } \\
\text { (2005), Zhang } \\
(2009)\end{array}$} \\
\hline \multirow[t]{5}{*}{ Fisik) } & $\mathrm{F} 2$ & Fasilitas akomodasi yang menarik & \\
\hline & F3 & Ketersediaan dokumen informasi dan buku catatan & \\
\hline & F4 & $\begin{array}{l}\text { Tampilan fisik dari tim pendamping jasa tur dan hotel } \\
\text { (kerapian, dsb) }\end{array}$ & \\
\hline & F5 & Fasilitas harus nyaman & \\
\hline & F6 & Fasilitas harus tampil menarik dan estetik & \\
\hline
\end{tabular}




\begin{tabular}{|c|c|c|c|}
\hline \multirow[t]{5}{*}{ Variabel Laten } & \multicolumn{2}{|r|}{ Indikator } & \multirow[t]{5}{*}{ Sumber } \\
\hline & F7 & Petugas tampil bersih dengan seragam yang rapi & \\
\hline & F8 & Eksterior ruangan terawat dengan baik & \\
\hline & F9 & Interior ruangan terawat dengan baik & \\
\hline & F10 & Ruangan bersih & \\
\hline \multirow{6}{*}{$\begin{array}{l}\text { Safety E Security } \\
\text { (keselamatan } \\
\text { dan Keamanan) }\end{array}$} & $\mathrm{X} 1$ & $\begin{array}{l}\text { Produk atau layanan wisata tidak membahayakan } \\
\text { nyawa, merusak kesehatan, serta integritas konsumen }\end{array}$ & \multirow{6}{*}{$\begin{array}{l}\text { Moon et al. } \\
\text { (2011),Eraqi } \\
\text { (2006), Narayan et } \\
\text { al (2008) }\end{array}$} \\
\hline & $\mathrm{X} 2$ & Keamanan di tempat menginap & \\
\hline & $\mathrm{X} 3$ & Keamanan turis di tempat yang dikunjungi & \\
\hline & $\mathrm{X} 4$ & $\begin{array}{l}\text { Keselamatan perjalanan domestik (pesawat, kereta, bis, } \\
\text { taksi) }\end{array}$ & \\
\hline & $\mathrm{X} 5$ & Kemungkinan gangguan dari pengemis & \\
\hline & $\mathrm{X} 6$ & Kemungkinan gangguan dari pedagang & \\
\hline \multirow{6}{*}{$\begin{array}{l}\text { Communication } \\
\text { (Komunikasi) }\end{array}$} & K1 & Biaya/harga yang dibayarkan dijelaskan dengan baik & \multirow{6}{*}{$\begin{array}{l}\text { Moon et al. (2011), } \\
\text { Zhang (2009) }\end{array}$} \\
\hline & K2 & $\begin{array}{l}\text { Saya menerima perhatian yang tidak berbeda dibanding } \\
\text { pengunjung lainnya }\end{array}$ & \\
\hline & K3 & Petugas mencari tahu kebutuhan khusus saya & \\
\hline & K4 & Petugas mengantisipasi kebutuhan saya & \\
\hline & K5 & $\begin{array}{l}\text { Komunikasi yang lancar dan mudah dipahami dengan } \\
\text { wisatawan }\end{array}$ & \\
\hline & K6 & $\begin{array}{l}\text { Kemudahan berkomunikasi dengan penduduk dalam } \\
\text { bahasa yang bisa difahami oleh turis (asing) dengan } \\
\text { penduduk setempat (misal: bahasa Inggris) }\end{array}$ & \\
\hline \multirow{3}{*}{$\begin{array}{l}\text { Hospitality/ } \\
\text { Friendliness } \\
\text { (Keramah } \\
\text { tamahan) }\end{array}$} & R1 & Kesopanan petugas di pintu masuk & \multirow{3}{*}{$\begin{array}{l}\text { Moon, et al. } \\
\text { (2011), Narayan et } \\
\text { al.(2008) }\end{array}$} \\
\hline & R2 & Kesopanan petugas di tempat menginap & \\
\hline & R3 & Keramahtamahan penduduk diluar tempat menginap & \\
\hline \multirow{8}{*}{$\begin{array}{l}\text { Hygiene } \\
\text { (Kesehatan) }\end{array}$} & $\underline{S 1}$ & Fasilitas akomodasi aman dan bersih & \multirow{8}{*}{$\begin{array}{l}\text { Narayan et } \\
\text { al.(2008),Eraqi } \\
\text { (2006) }\end{array}$} \\
\hline & S2 & Standar keamanan makanan & \\
\hline & S3 & $\begin{array}{l}\text { Kebersihan dan kesehatan di fasilitas kedatangan } \\
\text { (stasiun, terminal, bandara) }\end{array}$ & \\
\hline & S4 & Kebersihan dan kesehatan di tempat menginap & \\
\hline & S5 & Kebersihan dan kesehatan di lokasi kunjungan wisata & \\
\hline & S6 & $\begin{array}{l}\text { Kebersihan dan kesehatan restoran diluar tempat } \\
\text { menginap }\end{array}$ & \\
\hline & S6 & Kebersihan dan kesehatan kondisi/keadaan jalan & \\
\hline & S8 & Tingkat kesehatan dari makanan. & \\
\hline $\begin{array}{l}\text { Accessibility } \\
\text { (kemudahan } \\
\text { untuk diakses) }\end{array}$ & $\mathrm{C} 1$ & $\begin{array}{l}\text { Layanan, komunikasi, dan bentuk fisik harus dapat } \\
\text { digunakan oleh wisatawan, tanpa perbedaan, termasuk } \\
\text { orang cacat }\end{array}$ & Eraqi(2006) \\
\hline $\begin{array}{l}\text { Transparency } \\
\text { (Transparansi) }\end{array}$ & T1 & $\begin{array}{l}\text { Penyediaan informasi jujur tentang karakteristik produk } \\
\text { dan harganya }\end{array}$ & Eraqi (2006) \\
\hline $\begin{array}{l}\text { Authenticity } \\
\text { (Keaslian) }\end{array}$ & O1 & Produk berbeda dengan produk lain yang sejenis & Eraqi (2006) \\
\hline $\begin{array}{l}\text { Harmony } \\
\text { (Keserasian / } \\
\text { keselarasan) }\end{array}$ & L1 & $\begin{array}{l}\text { Keselarasan antara menjaga kualitas produk bagi } \\
\text { wisatawan dan lingkungan alam serta sosial-ekonomi }\end{array}$ & Eraqi(2006) \\
\hline \multirow[t]{5}{*}{ Informasi } & I1 & $\begin{array}{l}\text { Ketersediaan pusat informasi turis di pos kedatangan } \\
\text { (stasiun, terminal, bandara) }\end{array}$ & \multirow[t]{5}{*}{$\begin{array}{l}\text { Narayan et al. } \\
(2008)\end{array}$} \\
\hline & $\mathrm{I} 2$ & Ketersediaan pusat informasi turis di tempat menginap & \\
\hline & $\mathrm{I} 3$ & Ketersediaan pusat informasi turis di lokasi wisata & \\
\hline & I4 & Literatur informatif tentang lokasi wisata tersedia & \\
\hline & I5 & Ketersediaan pemandu khusus di bis wisata & \\
\hline
\end{tabular}




\begin{tabular}{|c|c|c|c|}
\hline \multirow[t]{4}{*}{ Variabel Laten } & \multicolumn{2}{|r|}{ Indikator } & \multirow[t]{4}{*}{ Sumber } \\
\hline & I6 & Ketersediaan pemandu khusus di lokasi wisata & \\
\hline & I7 & $\begin{array}{l}\text { Kelengkapan informasi yang memadai terkait pelayanan } \\
\text { disampaikan }\end{array}$ & \\
\hline & I8 & Kelengkapan informasi pada pertunjukan/hiburan lokal & \\
\hline \multirow{5}{*}{$\begin{array}{l}\text { Service } \\
\text { responsibility } \\
\text { (tanggung jawab } \\
\text { layanan) }\end{array}$} & $\mathrm{J} 1$ & Petugas ramah dan menyenangkan & \multirow[t]{5}{*}{ _Prabaharan (2008) } \\
\hline & $\mathrm{J} 2$ & Memahami kebutuhan khusus & \\
\hline & $\mathrm{J} 3$ & Mempererat hubungan pertemanan & \\
\hline & $\mathrm{J} 4$ & Petugas memberi perhatian khusus kepada saya & \\
\hline & J5 & $\begin{array}{l}\text { Petugas seharusnya memberikan waktu khusus bersama } \\
\text { pengunjung }\end{array}$ & \\
\hline \multirow[t]{3}{*}{$\begin{array}{l}\text { Service product } \\
\text { (produk layanan) }\end{array}$} & B1 & $\begin{array}{l}\text { Perjanjian/kontrak yang mudah saat kedatangan (di } \\
\text { bandara, stasiun, terminal) dengan petugas tur/agen hotel }\end{array}$ & \multirow[t]{3}{*}{ Prabaharan (2008) } \\
\hline & B2 & $\begin{array}{l}\text { Lokasi dan hubungan / kontak yang mudah dengan } \\
\text { pendamping jasa tur dan hotel }\end{array}$ & \\
\hline & B3 & Layanan diberikan tepat waktu & \\
\hline \multirow[t]{5}{*}{ Food (Makanan) } & M1 & Makanan yang berkualitas tinggi & \multirow{5}{*}{$\begin{array}{l}\text { Narayan, et } \\
\text { al.(2008) }\end{array}$} \\
\hline & M2 & $\begin{array}{l}\text { Rasa dari makanan lokal yang disajikan di tempat } \\
\text { menginap }\end{array}$ & \\
\hline & M3 & $\begin{array}{l}\text { Rasa dari makanan lokal yang disajikan di luar tempat } \\
\text { menginap }\end{array}$ & \\
\hline & M4 & $\begin{array}{l}\text { Ketersediaan makanan (makanan yang disukai) di } \\
\text { tempat menginap }\end{array}$ & \\
\hline & M5 & $\begin{array}{l}\text { Ketersediaan makanan (makanan yang disukai) di } \\
\text { tempat menginap }\end{array}$ & \\
\hline \multirow{6}{*}{$\begin{array}{l}\text { Customer } \\
\text { Satisfaction } \\
\text { (kepuasan } \\
\text { pelanggan) }\end{array}$} & G1 & Lama masa berkunjung & \multirow[t]{6}{*}{ Kangogo(2013) } \\
\hline & G2 & Loyalitas Pelanggan Daerah Wisata & \\
\hline & G3 & Penjualan berulang & \\
\hline & G4 & $\begin{array}{l}\text { Arahan / cerita dari pengunjung sebelumnya kepada } \\
\text { orang lain }\end{array}$ & \\
\hline & G5 & Penanganan terhadap komplain konsumen & \\
\hline & G6 & Tamu yang datang kembali & \\
\hline \multirow{20}{*}{$\begin{array}{l}\text { Destination } \\
\text { Competitiveness } \\
\text { (Daya Saing } \\
\text { Lokasi wisata) }\end{array}$} & W1 & Faktor ketersediaan acara - acara / kegiatan khusus & \multirow[t]{20}{*}{ Crouch (2007) } \\
\hline & W2 & Faktor Fisiografi dan Iklim & \\
\hline & W3 & Faktor Budaya dan Sejarah & \\
\hline & W4 & Faktor menggabungkan beberapa kegiatan & \\
\hline & W5 & Faktor Hiburan & \\
\hline & W6 & Faktor Suprastruktur & \\
\hline & W7 & Faktor Hubungan Pasar & \\
\hline & W8 & Faktor Infrastruktur & \\
\hline & W9 & Faktor Aksesibilitas & \\
\hline & W10 & Faktor Memfasilitasi Sumber Daya & \\
\hline & W11 & Faktor Keramahan & \\
\hline & W12 & Faktor Dukungan Pengelola & \\
\hline & W13 & Faktor Kebijakan Politik & \\
\hline & W14 & Faktor Sistem yang terdefinisi & \\
\hline & W15 & Faktor Filosofi / nilai - nilai & \\
\hline & W16 & Faktor Visi & \\
\hline & W17 & Faktor Positioning / merk & \\
\hline & W18 & Faktor Pengembangan & \\
\hline & W19 & Faktor Analisa kompetisi / analisa kolaborasi & \\
\hline & W20 & Faktor Evaluasi dan monitoring & \\
\hline
\end{tabular}




\begin{tabular}{ll}
\hline Variabel Laten & Sumber \\
\hline & W11 Faktor Audit \\
$\frac{\text { W22 Faktor organisasi }}{\text { W23 Faktor Pemasaran }}$ & $\frac{\text { W24 Faktor kualitas layanan }}{\text { W25 Faktor informasi / penelitian }}$ \\
$\frac{\text { W26 Faktor pengembangan sumber daya manusia }}{\text { W27 Faktor keuangan dan modal ventura }}$ \\
$\frac{\text { W28 Faktor Pengelolaan Pengunjung }}{\text { W29 Faktor Manajemen Krisis }}$ \\
$\frac{\text { W30 Faktor Pengelolaan Sumberdaya }}{\text { W31 Faktor lokasi }}$ \\
$\frac{\text { W33 Faktor keselamatan / keamanan }}{\text { W34 Faktor ketergantungan }}$ \\
\hline W35 Faktor kesadaran / imej \\
\hline
\end{tabular}

\section{SIMPULAN}

Model konseptual terdiri dari enam belas (16) dimensi kualitas layanan pariwisata yang akan mempengaruhi atau memiliki hubungan yang positif dengan kepuasan pelanggan (wisatawan atau turis). Kepuasan pelanggan memiliki pengaruh yang positif terhadap keunggulan daerah wisata (destination competitiveness). Untuk mengukur daya saing (keunggulan) daerah wisata menggunakan 36 indikator. Model konseptual ini nantinya diharapkan dapat mengukur kepuasan wisatawan di antara daerah wisata yang menjadi objek, juga mengukur tingkat daya saing masing-masing objek tersebut, sekaligus mengetahui faktor apa yang paling berpengaruh terhadap daya saing tujuan wisata. Faktor-faktor yang paling berpengaruh itu akan menjadi fokus perhatian ke depan dalam rangka peningkatan kualitas layanan daerah wisata. Untuk mendapatkan semua tolok ukur tersebut maka selanjutnya perlu dilakukan pengambilan data, bisa melalui wawancara maupun penyebaran kuesioner kepada wisatawan selaku kosumen.

\section{DAFTAR PUSTAKA}

Atilgan, E., S. Akinci, S. Aksoy, 2003, Mapping Service Quality ini Tourism Industry, Managing Service Quality, Vol. 13 Number 5, Emerald, p. 412-422
Caro, L.M., J.A.M. Garcia, 2008, Developing a multidimensional and hierarchial service quality model for travel agency industry, Tourism Management 29, p. 706-720.

Crouch, G.I., 2007, Modelling destination competitiveness: a survey and analysis of the impact of competitiveness attributes, National Library of Australia Cataloguing in Publication Data.

Eraqi, M. I., 2006, Tourism Service Quality (Tourservqual) in Egypt : The Viewpoints of External and Internal Customers, Benchmarking : An International Journal, Emerald Vol. 13 No. 4 pp. 469 - 492.

Haghkhah, A.,M. Nosratpour, A. Ebrahimpour, A. B. Abd Hamid, 2011, The Impact Of Service Quality On Tourism Industry, 2nd International Conference on Business and Economic Research Proceeding.

Ho, C., Y. Lee, 2007, The development of an $e$-travel service quality scale, Tourism Management (28), p. 1434-1449.

Hung-Chih Yu, A., D. Morais, G. Chick, 2005, Service Quality in Tourism: A case study of the 2001 study tour of Taiwan, Proceedings of the 2005 Northeastern Recreation Research Symposium. 
Kangogo, E. J., Musiega, J. Manyasi, 2013, Effect Of Customer Satisfaction On Performance Of The Hotel Industry In The Western Tourism, European Journal Of Business and Management Vol. 5 No. 14 pp 87 - 99.

Liangi, S. N., D. Susanto, 2010, Analisa Pengaruh Kepuasan atas Atribut Destinasi Wisata Rohani Terhadap ReVisiting Commitment Pengunjung Di Pertapaan Putri Karmel Tumpang Malang, Tugas Akhir, Universitas Kristen Petra, Surabaya.

Martin-Cejas, R.R., 2006, Tourism Service Quality Begins at the Airport, Tourism Management 27, Elsevier, p. 874-877.

Moon, K.S., M. Kim, Y.J. Ko, D.P. Connaughton, J.H. Lee, 2011, The Influence of Consumer's Event Quality Perception on Destination Image, Managing Service Quality, Vol. 21 Number 3, Emerald, p. 287-303.

Narayan, B., C. Rajendran, L.P. Sai, 2008, Scales to measure and benchmark service quality in tourism industry: A secondorder factor approach, Benchmarking: An International Journal vol 15 no 4, pp 469-493.

Parasuraman, V.A. Zeithaml, L. Berry, 1990, Delivering Quality Service - Balancing Customer Perceptions and Expectations, New York: The Free Press.
Prabaharan, B., A. Arulraj, V. Rajagopal, 2008, Service Quality on Tourism : Application of Structural Equation Modelling, Conference on Tourism in India - Challenges Ahead.

Sulistiyani, E., 2010, Membangun Loyalitas Wisatawan Melalui Peningkatan Kualitas Objek Wisata, Promosi Kepuasan Wisatawan di Kawasan Wisata Tawangmangu Karanganyar, Jurnal Pengembangan Humaniora Vol 10. No. 3.

Tsaur, S., Y. Lin, 2004, Promoting service quality in tourist hotels: the role of HRM practices and service behavior, Tourism Management (25), p. 471-481.

WTO, 2003, Quality standards, WTO Tourism Quality, World Tourism Organisation, available at: www. world-tourism.org.

Zhang, J., 2009, An Investigation into the Guests' Perceived Service Quality of the Bedand-Breakfast and Guest House Market Industry in the Nelson Mandela Bay Area, Dissertation, Nelson Mandela Metropolitan University.

http:/ / www.antarajateng.com / detail/index.php?id=73597\#. UWHsTa6X9bw diakses 8 April 2013. 